\title{
SOME MARINE FUNGI FROM LAXMANPUR BEACH AT NIEL ISLAND OF ANDAMAN
}

\author{
${ }^{1}$ A.R. Tuwar*, ${ }^{2}$ J.B. Cholake and ${ }^{3}$ R.K. Aher \\ ${ }^{1}$ Arts, Commerce $\&$ Science College Sonai, Tal: Newasa, Dist: Ahmednagar. \\ ${ }^{2}$ Padmashri Vikhe Patil College of Arts, Science and Commerce College Pravaranagar. \\ ${ }^{3}$ New Arts, Commerce and Science College Parner, Tal-, Parner, Dist -Ahmednagar. \\ *Corresponding author: tuwarar@gmail.com
}

\begin{abstract}
:
The present study deals with marine fungi from Laxmanpur beach at Niel island of Andaman. The dead, decaying, intertidal and submerged mangrove wood samples were collected from Laxmanpur beach. These samples examined for colonization of marine fungi. Ten species of marine fungi were isolated and illustrated. Out of these marine fungi 5 species of Ascomycota (Aigialus grandis Kohlm. and Schatz, Eutypa bathurstensis K. D. Hyde and Rappaz, Savoryella lignicola Jones and Eaton, Halorosellinia oceanica (S.Schatz) Whalley et al and Verruculina enalia (Kohlm) Kohlm and Volkm-.Kohlm.),while 5 species from Mitosporic fungi (Alternaria sp., Clavatospora bulbosa (Anastasiou) Nakagiri and Tubaki, Epicoccum purpurasens Ehrenb. and Schlecht, Halenospora varia (Anastasiou) Jones and Periconia prolifica Anastasiou). Out of these fungi Alternaria sp is very common fungi reported from most of the wood samples. All ten higher marine fungi were first time reported from Laxmanpur beach of Andaman Island.
\end{abstract}

Key words: - Mangrove, Marine Fungi, Laxmanpur beach, Niel Island and Andaman.

\section{INTRODUCTION:}

Laxmanpur beach is situated at Laxmanpur villageat Niel island of Andaman. Laxmanpur beach is located $39 \mathrm{~km}$ from Port-blair and 2 $\mathrm{km}$ from Neil jetty. Laxmanpur beach is famous beach of Niel Island. Marine fungi play an important role in nutrient regeneration cycle as decomposers of decaying organic matter. A range of fungi occurs in the mangrove ecosystem, although their composition and frequency of occurrence vary with location. Mangroves sustain a wide range of fungi and the fungal diversity reflects the availability of substrate for colonization. Mangroves are the evergreen forest common to tropical and subtropical coastal regions and occur along estuaries, coastal lagoons and backwaters where the regular flow of the tides bring along with mixing of fresh water from rain and land drainage with marine coastal waters.

An extensive ecological study on mangroves fungi in India were studied by Borse (1988), Ravikumar (1991), Chinnaraj and Untawale, (1992), Ravikumar and Vitthal, (1996), Borse, et al., (2012), Tuwar et al., (2012), However study on Andaman \& Nicobar Island is merger. Some extent Chinnaraj, (1993), Baskaran R., et al., (2012) and Tuwar \& Cholake., (2013) study the marine fungi from mangroves from Andaman \& Nicobar Islands. This data provides information on the distribution of these marine fungi from Mangrove ecosystem of Laxmanpur beach at Niel island of Andaman. The taxonomy, morphology and ecology of these fungi will be illustrated and discussed. 


\section{MATRIALS AND METHODS:}

Samples of dead and decayed mangrove wood, intertidal wood, driftwood and submerged wood were collected randomly during low tide period from Laxmanpur beach at Niel island of Andaman. The samples were placed in plastic bags and sealed well in order to avoid moisture loss. On returning to the laboratory, samples with debris and fouling organisms were washed thoroughly with running tap water. Surface fouling organisms were scrapped off, following rinsing in tap water. The fresh samples were examined using a stereomicroscope for fungal growth. After initial observations, samples were incubated in plastic boxes and kept moist by spraying with sterile seawater and periodically examined for presence of fungal growth.

The permanent slides were prepared as per suggested by Volkmann- Kohlmeyer and Kohlmeyer, 1996 and Kohlmeyer and Kohlmeyer 1972. The measurements of various parts of fungi and their photomicrographs were taken. The identification of the marine fungi was made with the help of Kohlmeyer and Kohlmeyer, 1979; Kohlmeyer and Volkmann-Kohlmeyer, 1991; Hyde and Sarma 2000 and other relevant literature.

\section{RESULTS AND DISCUSSION:}

Chinnaraj (1993) isolated 63 marine fungi from mangroves of Andaman and Nicobar Islands. The results of our investigation total ten species of marine fungi were isolated and illustrated. Out of these marine fungi 5 species of Ascomycota (Aigialus grandis Kohlm. and Schatz, Eutypa bathurstensis K. D. Hyde and Rappaz, Savoryella lignicola Jones and Eaton, Halorosellinia oceanica (S.Schatz) Whalley et al and Verruculina enalia (Kohlm) Kohlm and Volkm-.Kohlm.) and 5 species from Mitosporic fungi (Alternaria sp., Clavatospora bulbosa (Anastasiou) Nakagiri and Tubaki, Epicoccum purpurasens Ehrenb. and Schlecht, Halenospora varia (Anastasiou) Jones and Periconia prolifica Anastasiou). Out of these fungi Alternaria sp is very common fungi reported from most of the wood samples.This data provides information on the distribution of these fungi in India, apart from description and illustrations. The taxonomy, morphology and ecology of these fungi will be illustrated and discussed.

\section{Taxonomic Account of Fungi}

1. Aigialus grandis Kohlm. and S. Schatz, Trans. Br. Mycol. Soc., 85: 699, 1985.

Ascomata: 244-470 $\mu \mathrm{m}$ thick, globose, ostiolate, carbonaceous to coriaceous, black, gregarious. Peridium: two-layered; composed of elongate, more or less irregular cells. Ostioles: 32-80 $\mu \mathrm{m}$ diam., Pseudoparaphyses: $1-2 \mu \mathrm{m}$ in diam., trabeculate, unbranched at the base, embedded in a gelatinous matrix. Asci: 290-380 $\mu \mathrm{m}$ x 30-34 $\mu \mathrm{m}$, eight-spored, cylindrical, long-pedunculate, thick-walled, fissitunicate, with a refractive apical plate in the ectoascus and a refractive apical ring in the endoascus. Ascospores: 88-92 $\mu \mathrm{m}$ long, 20-22 $\mu \mathrm{m}$ broad, 12-16 $\mu \mathrm{m}$ thick, biseriate, ellipsoidal to broadly fusiform in frontal view, in side

view flat on one side, convex on the other, muriform, with 14-16 trans-septa and 1-3 longisepta in all but the end cells, slightly constricted at the septa, yellow-brown except for the hyaline or light brown apical cells, glabrous, 2-3 $\mu \mathrm{m}$ thick, with a gelatinous cap, around the apical and sub-apical cells.

2. Eutypa bathurstensis K. D. Hyde and Rappaz, Mycol. Res.97: 861, 1993.

Ascomata: $0.2-0.6 \mathrm{~mm}$ high, up to $0.8 \mathrm{~mm}$ wide, spherical to flattened, submerged in the wood, Necks: up to $0.3 \mathrm{~mm}$ long, Peridium: 
30-43 $\mu \mathrm{m}$ wide or wider near the ostiolar canal. Ostioles: poorly developed or conical, up to $280 \mu \mathrm{m}$ high, $129-177 \mu \mathrm{m}$ diam., Paraphyses: numerous, persistent. Asci: clavate, 26-42 $\mu \mathrm{m} \times$ 7.5-9.5 $\mu \mathrm{m}$, eightspored, Ascospores: $7 \times 2-3 \mu \mathrm{m}$. and olivebrown.

3. Halorosellinia oceanica (Schatz) Whalley, Jones, Hyde and Laessoe, Mycol. Res., 104: 368, 2000.

Hypoxylon oceanicum Schatz, Mycotaxon, 33: 413, 1988. Pseudostromata: 0.5-0.7 $\mu \mathrm{m}$ diameter, single, or in clusters, linear to suborbicular, Ascomata: 620-770 $\mu \mathrm{m}$ x 730$960 \mu \mathrm{m}$, subglobose to hemispherical, soft to leathery, black, ostioles papillate. Peridium: 25-32 $\mu \mathrm{m}$ wide, Paraphyses: $2-3 \mu \mathrm{m}$ wide at the base, abundant, persistent, remotely septate. Asci: eight-spored, 170-210 $\mu \mathrm{m}$ long, spore-bearing part 135-139

$\mu \mathrm{m}$ long, stipe 40-76 $\mu \mathrm{m}$ long, cylindrical, unitunicate, Ascospores: dark grey-olive to opaque brown, more or less inequilaterally ellipsoid, upper end broadly rounded, lower end slightly pointed, one-celled, 16-18 $\mu \mathrm{m} \times 6$ $8 \mu \mathrm{m}$, biguttulate, wall smooth and relatively thick, without appendages.

4. Savoryella lignicola Jones and Eaton, Trans. Br. Mycol. Soc., 52: 161, 1969.

Ascomata: $214-290 \mu \mathrm{m}$ high, $122-260 \mu \mathrm{m}$ in diameter, globose, subglobose or ellipsoidal, ostiolate, papillate, membranous and pale to dark brown. Necks: 76-140 $\mu \mathrm{m}$ long and upto 70-72 $\mu \mathrm{m}$ in diameter, brown with periphyses. Peridium: brown, Paraphyses present but sparse. Asci: 108-176 $\mu \mathrm{m}$ x 18-24 $\mu \mathrm{m}, 8-$ spored, cylindrical or clavate, short stalked, unitunicate, persistent, Ascospores: 28-34 $\mu \mathrm{m}$ $\mathrm{x} 10-20 \mu \mathrm{m}$, uni or triseriate, ellipsoidal, triseptate, constricted at the septa, central cells brown, apical cells smaller and hyaline.

5. Verruculina enalia (Kohlm) Kohlm. and Volk.-Kohlm., Mycol. Res.94: 689, 1990.
Didymosphaeria enalia Kohlm, Ber. Destch, Bot. Ges., 79: 28, 1966.

Ascomata: $2868-490 \mu \mathrm{m}$ high, $268-470 \mu \mathrm{m}$ in diameter, subglobose, ampulliform or depressed, ellipsoidal, partly or completely immersed, ostiolate, papillate, black, solitary. Peridium: 10-12 $\mathrm{mm}$ thick, thick-walled cells, with usually small lumina, merging on the outside into thick, brown, hyphae or stromatic structures. Papillae: 74-142 um long, 136-308 $\mu \mathrm{m}$ in diameter, Pseudoparaphyses: $1-2 \mu \mathrm{m}$ in diameter, septate, rarely branched, Asci:120$130 \mu \mathrm{m} \times 12-14 \mu \mathrm{m}$, eight-spored, cylindrical, pedunculate, bitunicate, thick-walled,

Ascospores: 18-22 $\mu \mathrm{m} \times 7-9 \mu \mathrm{m}$, obliquely uniseriate, ellipsoidal, one-septate, dark brown.

\section{Alternaria sp.}

Conidiophores: cylindrical, septate, simple or irregularly branched, straight or curved, basal cell occasionally swollen, smooth, yellowish to brown, singly. Conidia: enteroblastic- tretic, ovoid, obclavate, obpyriform or ellipsoidal, with a basal pore, tapering or not into an apical beak, muriform, constricted at the septa, smooth or rough, olivaceous to brown.

7. Clavatospora bulbosa (Anast.) Nakagiri and Tubaki , Bot. Mar., 28: 489, 1985.

Clavariopsis bulbosa Anastasiou, Mycologia, 53: $11,1961$.

Hyphae: 2-4 $\mu \mathrm{m}$ in diameter, septate, ramose, and fuscous. Conidiophores: 19-76 $\mu \mathrm{m} \times 2-4$ $\mu \mathrm{m}$, cylindrical, septate, simple or branched, hyaline. Conidia: tetra radiate, septate, slightly constricted at the septa, hyaline to light brown, basal arm one- septate, proximal cell 8-14 $\mu \mathrm{m} \quad \mathrm{x} \quad 4-8 \mu \mathrm{m}$ ellipsoidal or ovoid, truncate at the base, light brown, distal cell 7$12 \mu \mathrm{m} \times 6-14 \mu \mathrm{m}$, cylindrical or shortly three branched, fuscous, three divergent arms arising simultaneously from the inflated distal cell of basal arm, 22-60 $\mu \mathrm{m} \times 4-6 \mu \mathrm{m}$, cylindrical, one-to-five septate and light 
brown. One armed conidia: Conidia consisted of only single arm also observed, these are grey brown, 5-10 celled, 56-60 $\mu \mathrm{m} \times 6-9 \mu \mathrm{m}$, constricted around septa, basal and apical cells lighter color.

8. Halenospora varia (Anastasiou) E.B. G. Jones, Fungal Diversity, 35:154, 2009. Zalerion varium Anastasiou Can. J. Bot., 41: 1136, 1963 (as Z. Varia).

Hyphae: septate, branched, immersed, hyaline, Conidiophores: up to $30 \mu \mathrm{m}$ long, 2$3 \mu \mathrm{m}$ in diameter, micronematous, simple, cylindrical, septate, sometimes absent, superficial, hyaline to light olive colored. Conidia: 16-60um x 13-44 $\mu \mathrm{m}$, solitary, irregularly helicoid or coiled in three planes, forming a knot or ball of about 10 to 28 cells. Conidial filament lateral, rarely branched or subtending an additional conidium, thickwalled, smooth, brown to dark brown, appearing black in mass. Cells 6-13 $\mu \mathrm{m} \times \mathrm{x}$ $11 \mu \mathrm{m}$.

9. Periconia prolifica Anastasiou, Nova Headwigia, 6: 260, 1963.

Conidiophores: 5-18 $\mathrm{mm}$ × $3 \mu \mathrm{m}$; cylindrical, septate, simple or branched, hyaline. Conidiogenous cell: ellipsoidal or ovoid, hyaline, produced acrogenously. Conidia: 6-8 $\mu \mathrm{m}$ in diameter, one-celled, subglobose or ovoid, smooth, thick-walled, light brown with a reddish or dark brown, developing basipetally, catenulate, cells finally separating.

10. Epicoccum purpurascens Ehrenb. and Schlecht Synopsis Plantarum Cryptogamarum, 136, 1824.

Conidiophores: 4-14 $\mu \mathrm{m} \quad \mathrm{x} \quad 3-6 \mu \mathrm{m}$ macronematous or semimacronematous mononematous, forming a dense layer on the surface of the stroma, septate, simple or sometimes branched, short, straight or curved, smooth or verrucose, hyaline to light brown. Conidiogenous cells: monoblastic, integrated, terminal, determinate, cylindrical. Conidia: 16-
$22 \mu \mathrm{m}$ subglobose to pyriform, muriform with a basal scar surrounded by a light-colored protuberant basal cell, verrucose, dark golden brown, acrogenous solitary.

\section{SUMMARY AND CONCLUSION:}

In the present investigation ten species of marine fungi were isolated and illustrated. Out of these marine fungi 5 species of Ascomycota (Aigialus grandis Kohlm. and Schatz, Eutypa bathurstensis K. D. Hyde and Rappaz, Savoryella lignicola Jones and Eaton, Halorosellinia oceanica (S.Schatz) Whalley et al and Verruculina enalia (Kohlm) Kohlm and Volkm-.Kohlm.) and 5 species from Mitosporic fungi (Alternaria sp.,Clavatospora bulbosa (Anastasiou) Nakagiri and Tubaki, Epicoccum purpurasens Ehrenb. and Schlecht,

Halenospora varia (Anastasiou) Jones and Periconia prolifica Anastasiou). Out of these fungi Alternaria $\mathrm{sp}$ is very common fungi reported from most of the wood samples.

\section{ACKNOWLEDGEMENT:}

Authors are thankful to UGC, New Delhi, for financial support to Major Research Project, and Principal of Arts, Commerce \& Science College Sonai for providing research facilities.

\section{REFERENCES:}

Baskaran, R., Mohan, P.M., Sivakumar, P. and Sachithanandam, V. (2012). Phyllosphere Microbial Population of Ten True Mangrove species of the Andaman Island. International Journal of Microbiological Research 3 (2):124-127.

Borse, B. D. (1988). Frequency of occurrence of marine fungi from Maharashtra coast, India. Indian Journal of Marine Sciences, 17:165-167.

Borse, B.D., Bhat, D.J., Borse, K.N., Tuwar, A.R. and Pawar, N.S. (2012). Marine 
fungi of India (Monograph), Broadway Book Centre, Panjim, Goa. Pp. 471.

Chinnaraj, S. (1993). Higher marine fungi from mangroves of Andaman and Nicobar Islands. Sydowia, 45: 109-115.

Chinnaraj, S. and Utawale, A.G. (1992). Manglicolous fungi from India. Mahasager Vol.25 (1) pp.25-29.

Hyde, K. D. and Sarma, V. V. (2000). A pictorial key to higher marine fungi. In Marine Mycology- A Practical Approch. (Eds. Hyde, K.D. \& Pointing, S.B.), Fungal Diversity Press Research Series 1. The University of Hong Kong, Hong Kong, Pp. 205-270.

Kohlmeyer, J. and Kohlmeyer, E. (1972). Permanent microscopic mounts. Mycologia, 64: 666-669.

Kohlmeyer, J. and Kohlmeyer, E. (1979). MarineMycology: The Higher Marine fungi. Academic press, New York, pp. 689.

Kohlmeyer, J. and Volkmann-Kohlmeyer, B. (1991). Illustrated key to the filamentous higher marine fungi.

Botanica Marina, 34: 1-61

Ravikumar, D. R. (1991). Studies on fungi from mangroves of the East Coast of India. Ph.D. Thesis. University of Madras, India.

Ravikumar, D. R. and Vittal, B.P.R. (1996). Fungal diversity on decomposing biomass of mangrove plant Rhizophorain pichavaram estuary, east coast of India. Indian Journal of Marine Sciences, 25: 142-144.

Tuwar, A.R., Borse, K. N. and Borse B.D. (2012). Marine fungi from Goa coast (India)-II: Ad. Plant Sci., 25:207-2012.

Tuwar, A.R., and Cholake, J.B. (2013). Marine fungi from Havelock- Andaman \& Nicobar Island (India)-I: Flora \& Founa., 19 (1):22-25

Volkmann-Kohlmeyer, B. and Kohlmeyer, J. (1996). How to prepare truly permanent microscopic slides, Mycologist, 10:107-108. 